University of Nebraska - Lincoln

DigitalCommons@University of Nebraska - Lincoln

Faculty Publications from the Harold W. Manter Laboratory of Parasitology

2007

\title{
Nearctic Shrews, Sorex spp., as Paratenic Hosts of Soboliphyme baturini (Nematoda: Soboliphymidae)
}

\author{
S. V. Karpenko \\ Siberian Branch of the Russian Academy of Sciences \\ N. E. Dokuchaev \\ North Far Eastern Branch of the Russian Academy of Sciences \\ Eric P. Hoberg \\ National Parasite Collection, Animal Parasitic Diseases Laboratory, United States Department of \\ Agriculture, ehoberg@ggpl.arsusda.gov
}

Follow this and additional works at: https://digitalcommons.unl.edu/parasitologyfacpubs

Part of the Parasitology Commons

Karpenko, S. V.; Dokuchaev, N. E.; and Hoberg, Eric P., "Nearctic Shrews, Sorex spp., as Paratenic Hosts of Soboliphyme baturini (Nematoda: Soboliphymidae)" (2007). Faculty Publications from the Harold W. Manter Laboratory of Parasitology. 644.

https://digitalcommons.unl.edu/parasitologyfacpubs/644

This Article is brought to you for free and open access by the Parasitology, Harold W. Manter Laboratory of at DigitalCommons@University of Nebraska - Lincoln. It has been accepted for inclusion in Faculty Publications from the Harold W. Manter Laboratory of Parasitology by an authorized administrator of DigitalCommons@University of Nebraska - Lincoln. 


\title{
Nearctic Shrews, Sorex spp., as Paratenic Hosts of Soboliphyme baturini (Nematoda: Soboliphymidae)
}

\author{
S. V. Karpenko, ${ }^{1}$ N. E. Dokuchaev, ${ }^{2}$ and E. P. HoberG ${ }^{3,4}$ \\ ${ }^{1}$ Institute of Animal Systematics and Ecology of the Siberian Branch of the Russian Academy of Sciences, \\ Novosibirsk, Russia, \\ ${ }^{2}$ Institute of Biological Problems of the North Far Eastern Branch of the Russian Academy of Sciences, \\ Magadan, Russia, and \\ ${ }^{3}$ U.S. National Parasite Collection, Animal Parasitic Diseases Laboratory, U.S. Department of Agriculture, \\ Agricultural Research Service, BARC East 1180, Beltsville, Maryland 20705, U.S.A. \\ (e-mail: ehoberg@anri.barc.usda.gov)
}

ABSTRACT: Third-stage larvae (L3) of Soboliphyme baturini were discovered for the first time in shrews, Sorex cinereus and Sorex tundrensis from Alaska and the Nearctic. Shrews were found to be infected with L3 at Suloia Lake, southeastern Alaska, Togiak National Wildlife Refuge, southwestern Alaska, and at the Yukon-Charley Rivers National Preserve near the Yukon-Alaska border. Larvae in shrews from Alaska were morphologically indistinguishable from those known in both insectivores and arvicoline rodents from Russia. The occurrence of S. baturini in Alaskan insectivores further establishes shrews as important hosts in the transmission of $S$. baturini among mustelids and other carnivores and indicates for the first time the basis for a paratenic cycle in the Nearctic.

KEY WORDS: Nematoda, Soboliphyme baturini, shrews, paratenic hosts, northeast Asia, Alaska.

The third-stage larvae (L3) of Soboliphyme baturini Petrow, 1930 (Nematoda, Soboliphymidae) have been found repeatedly in small mammals from the Palearctic. In the Russian Far East (Magadan Region; Khabarovskii Krai; southern Primorskii Krai; Sakhalin Island), the shrews Sorex caecutiens Laxmann, Sorex camtschaticus Yudin, Sorex daphaenodon Thomas, Sorex gracillimus Thomas, Sorex isodon Turov, and Sorex unguiculatus Dobson are known as paratenic hosts of this helminth (Domnich, 1982; Karpenko, 1985; Dokuchaev, 2001, 2003, 2005). Additional reports of paratenic hosts include gray-sided voles, Clethrionomys rufocanus Sundevall, from the Tomsk Oblast (Karpenko et al., 1998).

Across the Holarctic, about 25 species of carnivorous mammals, including Martes zibellina (Linnaeus), Martes americana (Turton), Mustela vison Schreber, Martes erminea Linnaeus, and Gulo gulo (Linnaeus), are known as definitive hosts of $S$. baturini; felids and canids are rarely infected, and usually worms do not attain sexual maturity in hosts other than mustelids (Kontrimavichus, 1969). The prevalence and intensity of infection among some mustelids from territories of Siberia and the Far East of Russia are so high that epizootic outbreaks of Soboliphyme have been observed (Kontrimavichus, 1962). In captive sables (M. zibellina), intense in-

\footnotetext{
${ }^{4}$ Corresponding author.
}

fections may be accompanied by progressive anemia, vomiting of blood, and blood in the feces (Kadenatsii [1939] in Karmanova, 1968); infections may also be fatal (Oshmarin, 1963).

The life cycle of $S$. baturini was studied by E.M. Karmanova (1968). The intermediate hosts are oligochaetes of the family Enchytraeidae, in which larvae of S. baturini develop from first to third stage. Karmanova established experimentally that passive transmission could occur to mustelid definitive hosts through ingestion of infected oligochaetes, and considered that this represented the primary route for infection. She further postulated an alternative route for transmission via the ingestion of infected paratenic hosts such as insectivores and rodents (Karmanova, 1968; Zarnke et al., 2004).

Karmanova's assumption recently was confirmed based on material from the Magadan region. Shrews with high-intensity infections of larval $S$. baturini (up to 50 larvae per shrew) have been commonly reported. Such observations clearly indicate that insectivores alone can provide a predictable source of L3 S. baturini for mustelids throughout the year (Dokuchaev, 2001).

Although infections have been documented, currently information on the distribution of larval $S$. baturini in shrew paratenic hosts is limited to the Far East of Russia (Dokuchaev, 2003). Further data on the prevalence and intensity of larval S. baturini in mammalian paratenic hosts are limited, and informa- 
tion from North America is absent. We report results of collections of larval S. baturini in naturally infected shrews from Russia and Alaska, along with morphological comparisons of the third-stage larvae. These represent new host records for S. baturini in the Nearctic.

\section{MATERIALS AND METHODS}

Specimens of insectivores were examined from multiple localities in Alaska between 1994 and 2001. Twenty seven specimens of Sorex cinereus Kerr were caught between 8 and 12 July 1994 from the area of Suloia Lake, southeast Alaska, USA $\left(57^{\circ} 25^{\prime} 11^{\prime \prime} \mathrm{N}\right.$; $\left.135^{\circ} 43^{\prime} 12^{\prime \prime} \mathrm{W}\right)$. In August 2001, 302 shrews from the Togiak National Wildlife Refuge, southwest Alaska $\left(59^{\circ} 18^{\prime} 4^{\prime \prime} \mathrm{N}, 161^{\circ} 6^{\prime} 50^{\prime \prime} \mathrm{W} ; 59^{\circ} 18^{\prime} 25^{\prime \prime} \mathrm{N}\right.$, $\left.161^{\circ} 4^{\prime} 27^{\prime \prime} \mathrm{W}\right)$, previously preserved in ethanol and in the museum collections of University of Alaska Museum (Fairbanks, Alaska), were necropsied and examined for parasites; shrews were collected in 1996 by K. N. Peirce and J. V. Peirce. Additional specimens of S. cinereus and Sorex tundrensis Merriam were collected and examined from the Yukon-Charley Rivers National Preserve, Alaska, near the border of the Yukon Territory, Canada $\left(65^{\circ} 18^{\prime} 29^{\prime \prime} \mathrm{N}\right.$; $\left.142^{\circ} 02^{\prime} 08^{\prime \prime} \mathrm{W}\right)$.

Larvae were preserved in $70 \%$ ethanol or $10 \%$ formalin. Representative specimens from the area of Suloia Lake have been deposited in the Institute of Animal Systematics and Ecology of the Siberian Branch of the Russian Academy of Sciences, Novosibirsk, Russia. The others have been deposited in Institute of Biological Problems of the North Far Eastern Branch of the Russian Academy of Sciences, Magadan, Russia.

\section{RESULTS}

Soboliphyme baturini was found to represent a common nematode parasite in insectivores from Alaska, and third-stage larvae were found for the first time in shrews, $S$. cinereus and $S$. tundrensis, from the Nearctic. Among 27 S. cinereus at Suloia Lake, 11 of 12 overwintered shrews were infected by L3 of S. baturini; intensity of infection ranged from 4 to 10 . In contrast, 15 young of the year shrews were not infected. Prevalence of infection was $40.7 \%$ for all shrews and $91.7 \%$ for overwintered shrews only.

In August 2001, at the University of Alaska Museum, inspection of 302 shrews from Togiak National Wildlife Refuge showed that 24 S. cinereus and one $S$. tundrensis were infected by larvae of this nematode. Prevalence of infection was $8.3 \%$, and intensity ranged from 1 to $6($ mean $=1.9 \pm 0.32)$. In the summer of 2001, S. baturini larvae also were found in the same shrew species (data not available) from the Yukon-Charley Rivers National Preserve.

\section{Morphology of L3}

Ovoid capsules, which measured approximately 2.4-3.6 $\times 3.5-4.7 \mathrm{~mm}$ and were located on the abdominal side of the diaphragm, each contained single L3 of S. baturini. This is the first report of $S$. baturini in Nearctic shrews; thus, we present a comparative morphological analysis of the Palearctic and Nearctic forms based on comparisons of L3 in $S$. cinereus from the area of Suloia Lake (Table 1; Figs. 1-4).

The L3 of S. baturini have a well-developed cupshaped oral sucker and dense, coiled body. Dorsally, the cuticle of the sucker has clear longitudinal striations. The cuticle of the body has well-marked longitudinal and transverse striations. The hypodermis is marked by a rectangular pattern. The oral sucker is oval and slightly subterminal to the ventral side. On the border of the oral capsule are three pairs of cone-shaped papillae. The nerve ring is located near the base of the oral capsule. Seven cervical glands are disposed as in adult specimens of S. baturini (see Karmanova, 1968). The genital primordium is tubular and elongate. Sexual dimorphism is apparent in the L3, and the caudal bursa of the male is discernible.

Male (Fig. 1): Body length =3.7-5.9 mm (Table 1); maximum width, $0.32-0.35 \mathrm{~mm}$, attained near midlevel of intestine. Oral sucker $=0.50-0.55 \mathrm{~mm}$ length $\times 0.48-0.55 \mathrm{~mm}$ width. Esophagus $=0.90-1.35 \mathrm{~mm}$ long; esophageal glands begin to branch out at 0.030 $0.035 \mathrm{~mm}$ from orifice of oral sucker. Caudal region of body is slightly flattened dorso-ventrally. Bursa, rudimentary, is just beginning to form.

Female (Fig. 2): Body length $=3.2-5.7 \mathrm{~mm}$; maximum body width, $0.22-0.25 \mathrm{~mm}$, attained near mid-level of intestine. Oral sucker $=0.40-0.50 \mathrm{~mm}$ length $\times 0.38-0.55 \mathrm{~mm}$ width. Esophagus $=0.90$ $1.25 \mathrm{~mm}$ long; esophageal glands begin to branch out at $0.030-0.035 \mathrm{~mm}$ from orifice of oral sucker. Caudal extremity is pointed.

\section{Comparisons of larvae}

The nematodes from different specimens of $S$. cinereus varied greatly in esophageal length (overall range was about $0.40 \mathrm{~mm}$ ) and especially in body length (range was 2.2 and $2.5 \mathrm{~mm}$ for males and females, respectively). There was little variability in the dimensions of the remaining organs. Smaller larvae of $S$. baturini from one shrew had food remains, potentially blood or host tissue, in the esophagus and intestine (Fig. 3). Among larger larvae 


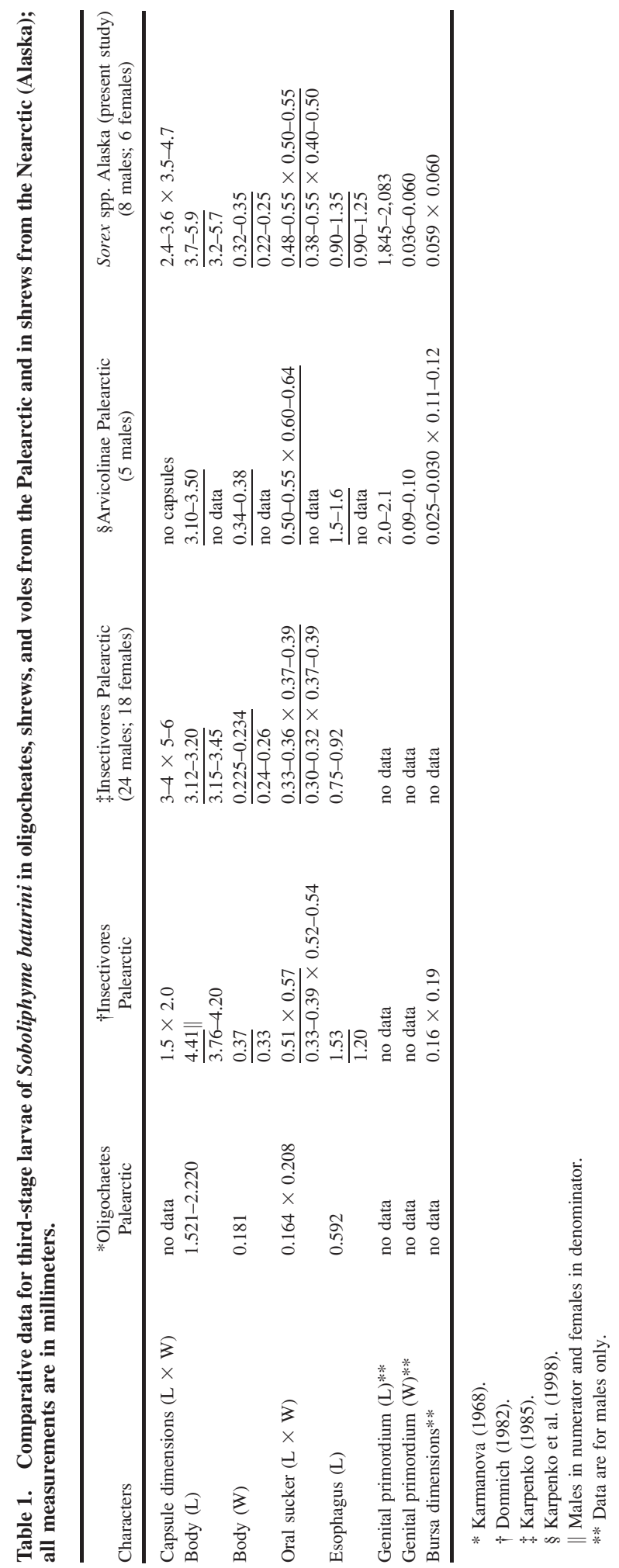



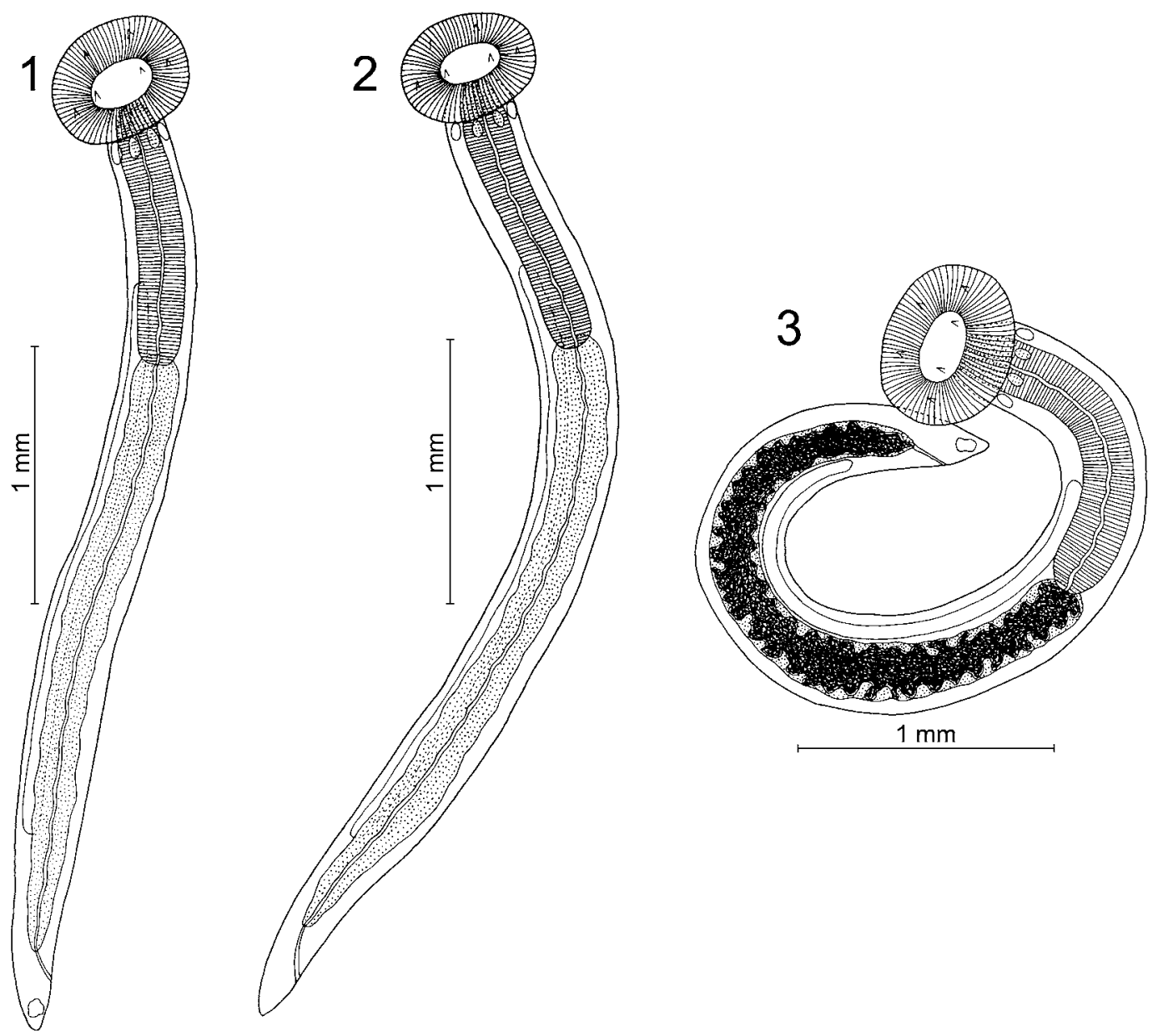

Figures 1-3. Larval Soboliphyme baturini from Suloia Lake, southeastern Alaska, U.S.A. 1. Male L3 from an overwintered female specimen of Sorex cinereus. 2. Female L3 from an overwintered female specimen of Sorex cinereus. 3. Male L3 with food particles, presumably host tissue or blood, retained in the intestinal tract, from an overwintered male of S. cinereus.

from another shrew, the esophagus and intestine were empty (Figs. 1, 2). We assume that in the first case, the larvae were younger and had encapsulated more recently. The presence of food remains in the esophagus and intestine of smaller larvae, which presumably have recently completed migration across the intestinal wall, may be compatible with this conclusion.

\section{DISCUSSION}

The nematode larvae in $S$. camtschaticus from the Palearctic and those in S. cinereus from the Nearctic were morphologically similar and did not differ significantly in size. Also, larvae of S. baturini in S. daphaenodon that were caught in Khabarovskii
Krai and in C. rufocanus from the Tomsk Oblast did not show any essential differences (Table 1). Thirdstage larvae from all mammalian hosts are in general agreement with those originally described by Karmanova (1968).

The morphological similarity for these L3 of S. baturini, irrespective of host and geographic origin, may further suggest, consistent with the current taxonomy, that there is only a single species with a widespread distribution in mustelid hosts from the Nearctic and Palearctic. This hypothesis and the relationship of Nearctic and Palearctic populations of S. baturini remain to be evaluated in detail based on phylogeographic analyses of mitochondrial DNA (A. Koehler et al., unpublished data). 


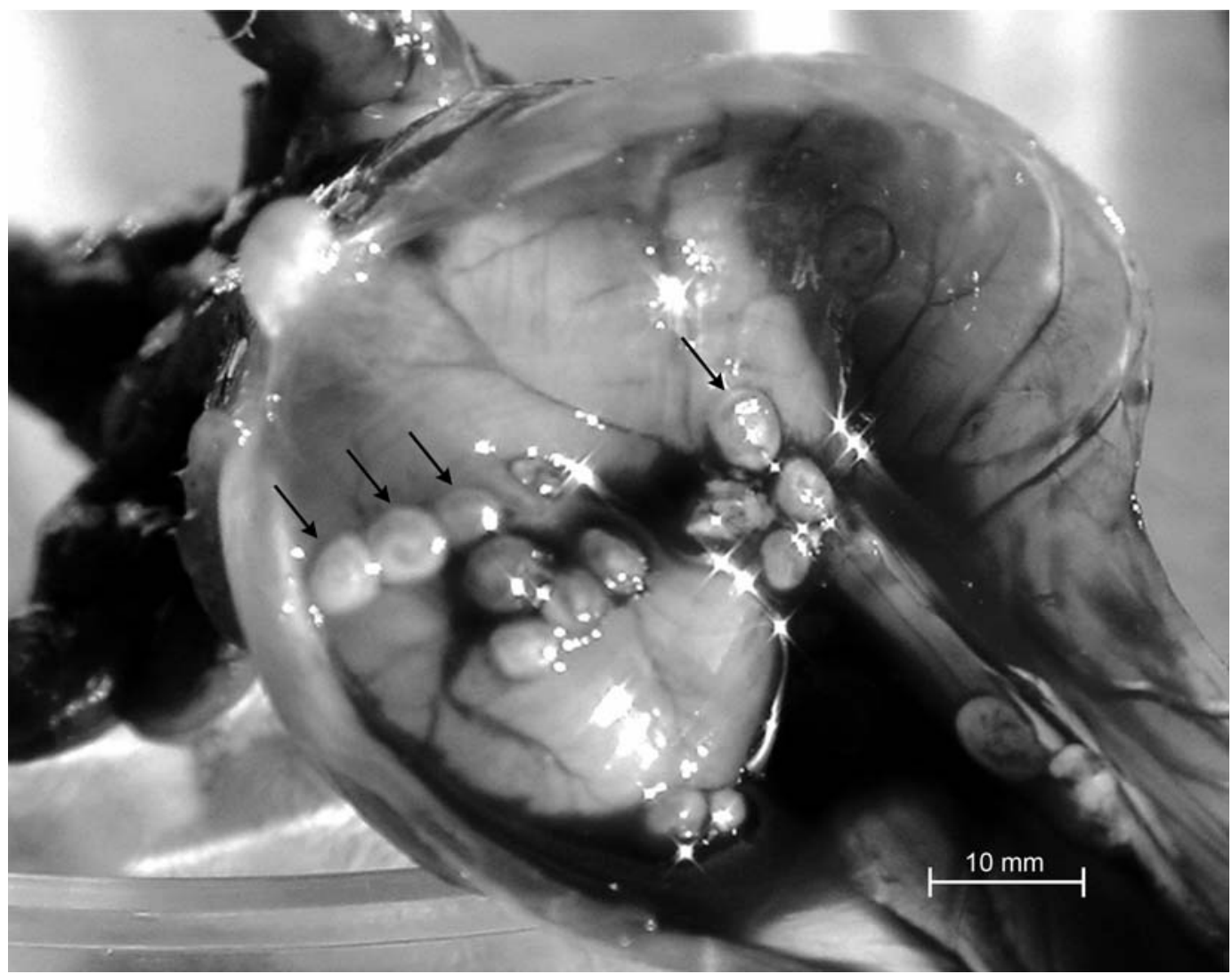

Figure 4. Larvae of Soboliphyme baturini encapsulated on the diaphragm of a shrew paratenic host; positions of some L3's are indicated by arrows.

The distribution of $S$. baturini in insectivores appears to be extensive across Alaska (from the southeast to subarctic latitudes, including the YukonCharley Rivers National Preserve) and likely coincides to some degree with the distribution of this parasite in mustelid definitive hosts in this region and elsewhere in North America (e.g., Hoberg et al., 1990; Zarnke et al., 2004). Martens are considered to be the most important host for these nematodes (Kontrimavichus, 1969), but apparently there are additional and currently unidentified environmental factors that serve as determinants of distribution (Zarnke et al., 2004). Food habits of primary mustelid hosts may be characterized as opportunistic, although arvicoline rodents are considered to be dominant through the annual cycle based primarily on scat analysis (e.g., Strickland et al., 1990). Insectivores, including species of Sorex, have been identified as prey for martens in Alaska but appear to be a minor component of the diet, most often represented during the winter (Buskirk and MacDonald, 1984; Clark et al., 1987). Our studies may establish the basis for recognizing shrews as important paratenic hosts involved in transmission of $S$. baturini.

The migration of $S$. baturini larvae in the paratenic host appears to be a complicated process. Larvae must first pass through the intestinal wall and then through host tissues to the site of localization near the diaphragm (Fig. 4). Such a pattern is consistent with the occurrence of blood or host tissue in the intestinal tract of the encapsulated helminth. Residues of presumed host tissue retained in the intestine or esophagus are only seen in relatively small specimens. This also suggests that, over time, larval parasites may deplete such resources during growth, and in our opinion, the larger larvae of $S$. baturini with empty intestines represent infections of longer duration.

The third-stage larvae of $S$. baturini exhibit considerable growth in mammalian paratenic hosts, but they remain encapsulated and do not develop to 
maturity in the gastrointestinal system (Table 1). It is interesting in this regard that insectivores serve as definitive hosts for at least 8 species of Soboliphyme that occur as adult parasites in shrews (Soboliphyme abei Asakawa, Kamiya, and Ohbayashi, 1988; Soboliphyme ataahai Ganzorig, Batsiakhan, Oku, and Kamiya, 2003; Soboliphyme jamesoni Read, 1952; Soboliphyme soricis Baylis and King, 1932) or moles (Soboliphyme hirudiniformis Kirshchenblatt, 1946; Soboliphyme caucasica Mazaberidse, 1965; Soboliphyme urotrichi Machida and Uchida, 1982; and Soboliphyme occidentalis Ribas and Casanova, 2004) primarily from the Palearctic (Karmanova, 1968; Ganzorig et al., 2003; Ribas and Casanova, 2006). Soboliphyme baturini remains the only species known in carnivores that circulates through shrew paratenic hosts and may be the only species with a Holarctic distribution; apparently reports of S. jamesoni in the Palearctic require confirmation (Ganzorig et al., 2003). The phylogeny for species of Soboliphyme is unresolved, and thus the relationships for faunas in mustelids and insectivores remain to be explored (Ganzorig et al., 2003).

Data from the current study further emphasize the importance of insectivores as paratenic hosts for $S$. baturini and suggest that shrews may be more prominent in the diets of martens than previously recognized. Insectivores, and to a lesser degree arvicoline rodents such as Clethrionomys spp., may serve a critical role in active transmission of $S$. baturini to mustelids and other carnivorous definitive hosts via predator-prey interactions. The mode of passive transmission to mustelids, canines, and other definitive hosts by ingestion of plants with infected oligochaetes may represent an incidental route for infection.

\section{ACKNOWLEDGMENTS}

We are grateful to J. A. Cook, Curator of Mammals, Museum of Southwest Biology, University of New Mexico, for access to specimens and opportunities to conduct field studies. We thank the University of Alaska Museum for access to specimens of shrews. The USDA, Forest Service in part supported field and laboratory studies by N. Dokuchaev in Alaska. We appreciate comments provided by A. Koehler on the distribution of Soboliphyme and food habits in martens. This work was also supported by the Russian Fund for Fundamental Research grant 05-04-49010. This paper is a contribution of the Beringian Coevolution Project, funded in part by grants from the National Science Foundation (0196095, 0415668) to J. A. Cook and E. P. Hoberg.

\section{LITERATURE CITED}

Buskirk, S. W., and S. O. MacDonald. 1984. Seasonal food-habits of marten in south-central Alaska. Canadian Journal of Zoology 62:944-950.

Clark, T. W., E. Anderson, C. Douglas, and M. Strickland. 1987. Martes americana. American Society of Mammalogists Mammal Species No. 289:1-8.

Dokuchaev, N. E. 2001. A significance of the shrews as paratenic hosts of nematodes Soboliphyme baturini. Overall results and prospects of the development of the mammalogy in Siberia. Pages 237-240 in Proceedings of the 1st Scientific Conference. Irkutsk, 2001. (In Russian.)

Dokuchaev, N. E. 2003. Distribution of nematodes Soboliphyme genus in shrews (Sorex) in the East of Russia. Pages 86-92 in Theriological investigations. Issue IV. Zoological Institute Russian Academy of Sciences, Saint Petersburg. (In Russian.)

Dokuchaev, N. E. 2005. The geographical features in occurrence of the nematode Soboliphyme baturini Petrov, 1930 in Sorex shrews. Pages 54-55 in Parasite Investigations in Siberia and the Far East of Russia, Materials of the 2nd Inter-Regional Scientific Conference, Novosibirsk, 15-20 September 2005. Novosibirsk, Russia, Art-Avenue Publishers.

Domnich, I. F. 1982. Shrew as paratenic hosts of nematode Soboliphyme baturini. Parasitologiya 16:497-499. (In Russian.)

Ganzorig, S., N. Batsaikhan, Y. Oku, and M. Kamiya. 2003. A new nematode, Soboliphyme ataahai sp. n. (Nematoda: Soboliphymidae) from Laxman's shrew, Sorex caecutiens Laxman, 1788 in Mongolia. Parasitology Research 89:44-48.

Hoberg, E. P., K. B. Aubry, and J. D. Brittell. 1990 Helminth parasitism in martens (Martes americana) and ermines (Mustela erminea) from Washington, with comments on the distribution of Trichinella spiralis. Journal of Wildlife Diseases 26:447-452.

Karmanova, E. M. 1968. Dioctophymidea of Animals and Man and Sickness caused by them. Fundamentals of Nematodology. Vol. 20. Akadameiia Nauk, Moscow. 263 pp. (In Russian.)

Karpenko, S. V. 1985. Shrew Sorex daphaenodon as paratenic hosts of nematodes Soboliphyme baturini Petrow, 1930. Proceedings of the Siberian Branch of Russian Academy of Science, Biological Series 3:7376. (In Russian.)

Karpenko, S. V., A. I. Chechulin, and A. V. Udaloi. 1998. Clethrionomys rufocanus Sundevall as paratenic hosts of nematodes Soboliphyme baturini Petrow, 1930. Pages 72-75 in The Parasites in the Nature Ecosystems and Risk Situations. SB RAAS (Siberian Branch of the Russian Academy of Agriculture Sciences), Novosibirsk. (In Russian.)

Kontrimavichus, V. L. 1962. To the soboliphymose epizootology of mustelids in Khabarovskii krai. Proceedings of the Helminthological Laboratory (USSR, Moscow) 12:37-42. (In Russian.)

Kontrimavichus, V. L. 1969. Helminths of mustelids and trends in their evolution. Izdatel'stvo Nauka, Moscow. 432 pp. (In Russian.)

Oshmarin, P. G. 1963. The parasitic worms of the mammals and birds in Primorskii krai. Academy of Sciences of USSR Press, Moscow. 323 pp. (In Russian.) 
Ribas, A., and J. C. Casanova. 2006. Helminth fauna of Talpa spp. in the Palearctic realm. Journal of Helminthology 80:1-6.

Strickland, M. A., C. W. Douglas, M. Novak, and N. P. Hunziger. 1990. Marten (Martes americana). Pages 599-612 in J. A. Chapman and G. A. Feldhamer, eds. Wild Mammals of North America: Biology, Manage- ment and Economics, 4th ed. Johns Hopkins University Press, Baltimore.

Zarnke, R. L., J. S. Whitman, R. W. Flynn, and J. M. Ver Hoef. 2004. Prevalence of Soboliphyme baturini in marten (Martes americana) populations from three regions of Alaska, 1990-1998. Journal of Wildlife Diseases 40:452-455. 